\title{
Delineation of groundwater potential zones utilising geospatial techniques in Kadiri watershed of Anantapur district, Andhra Pradesh, India
}

\begin{tabular}{lll}
\hline Paper received: 29.05 .2018 & Revised received: 04.08.2018 Re-revised received: 28.08.2018
\end{tabular}

\section{Authors Info \\ S. Pasupuleti', D.K. Sandilya', S. Singha* ${ }^{1 *}$ S.S. Singha ${ }^{1}$ and S. Saha \\ ${ }^{1}$ Department of Civil Engineering, Indian Institute of Technology (Indian School of Mines), Dhanbad, Dhanbad-826 004, India \\ ${ }^{2}$ Department of Chemical Engineering, Indian Institute of Technology (Indian School of Mines), Dhanbad-826 004, India}

*Corresponding Author Email : s.scivil077@gmail.com

\section{Edited by}

Dr. R. B. Raizada

Reviewed by Dr. Bhupendra Singh Naik Dr. P. S. Harikumar

\section{Abstract}

Aim : The objective of the study was to analyse and to identify the groundwater prospect zones (GWPZ) by developing groundwater potential zone map for Kadiri watershed of Anantapur district in Andhra Pradesh, India.

Methodology : Nine thematic layers were generated, i.e., geology, geomorphology, soil texture, soil depth, drainage density, slope, rainfall, lineament density and land use land cover of the study area, and based on multi criteria analysis (MCA) method revised ratings and weights were computed from interrelationship among the influencing layers. Integration of all thematic layers was done through weighted overlay technique (WOT) for developing groundwater potential zone map of the study area using GIS software.

Results : Five groundwater potential zones (GWPZ) were identified in the study area ranging from very poor to very good. According to the classification of GWPZ, 7.14\% (36.95 sq.km) and $39.88 \%$ (206.31 sq.km) of the study area falls under 'very good' and 'good' groundwater potential zone whereas $30.81 \%$ of study area, i.e., $159.35 \mathrm{sq} . \mathrm{km}$ accounts for moderate groundwater prospect. It was also observed that $17.77 \%$ (91.9 sq.km) and $4.40 \% \quad(22.77$ sq.km) accounts for 'poor' and 'very poor' groundwater potential zone in the study area, respectively. The major portion of good groundwater potential zone was found in the eastern part of the study area.

Interpretation : The research outcome of the

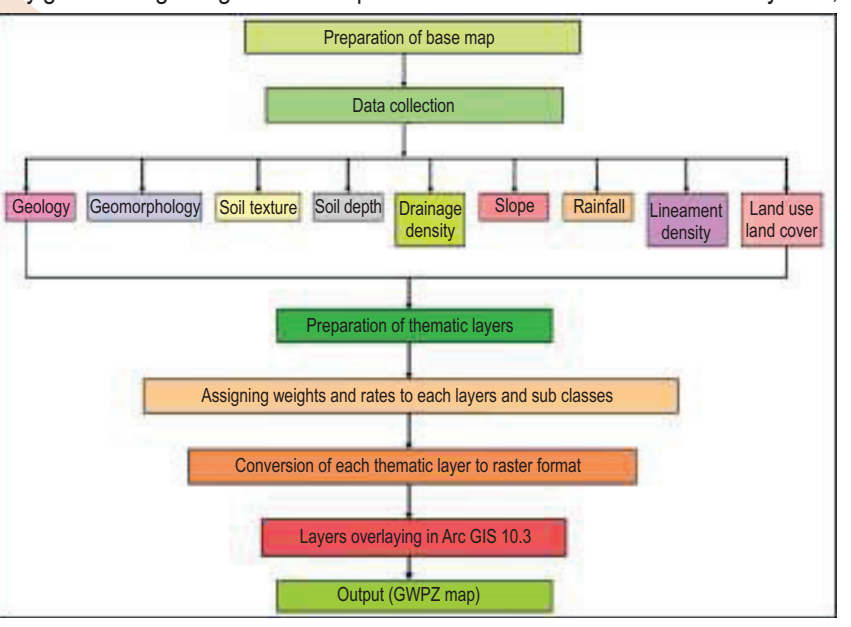
present study on status of groundwater availability will be helpful to the stake holders, local administration and policy makers in framing the guidelines for better planning, utilization and rejuvenation of depleting groundwater resources for sustainable development in the study area.

Key words: Delineation, Drought-prone, Groundwater potential zones, Multi criteria analysis, Weighted overlay technique,

How to cite : Pasupuleti, S., D.K. Sandilya, S. Singha, S.S. Singha and S. Saha: Delineation of groundwater potential zones utilising geospatial techniques in Kadiri watershed of Anantapur district, Andhra Pradesh, India. J. Environ. Biol., 40, 61-68 (2019). 


\section{Introduction}

Groundwater is a precious natural resource which is vital for social and economic development of the society and to maintain biodiversity in the area. At present, one of the natural pure water resources is groundwater which contributes approximately one-third of total water supply yearly (Magesh et al., 2012). Also, it contributes more than $85 \%$ in rural areas for domestic supply and due to huge amount of water drafting, groundwater is rapidly depleting day by day. India is experiencing drastic decline of groundwater resources due to over extraction leading to decline in groundwater levels, especially during the last two decades (Patra et al., 2018). So for proper management of this freshwater resource, potential assessment as well as monitoring of groundwater is very essential, and this situation demands time and cost-effective technique. To delineate the groundwater restoring zones, a large amount of data from various sources is required for groundwater development operation. Singha et al. (2017) reported in their study that various groundwater research works have been carried out to identify potential sites for groundwater assessment and management in India.

Remote Sensing (RS) and Geographic Information System (GIS) have contributed significantly in subsurface water studies. Geospatial technologies in conjunction with available high precision data have successfully aided in demarcating groundwater resources by providing necessary information on controlling factors to tap natural resource (Preeja et al., 2011). Moreover, GIS offers a work environment to effectively manage complex and exhaustive spatio-temporal data (Wieland and Pittore, 2017). Also, RS techniques aid in procuring spatiotemporal data of sizeable area within short span (Patra et al., 2018). Furthermore, RS and GIS based techniques have proved to be time and cost efficient in identification of groundwater potential zones (Leblanc et al., 2003; Tweed et al., 2007).

Integrated approach for identifying groundwater prospect zones has been adopted by many researchers, utilising different techniques (Gupta and Srivastava, 2010; Mallick et al., 2015; Agrawal and Garg, 2016). Some researchers have reported in their studies that RS and GIS is the most suitable tool for delineation of groundwater potential zones by assigning rank and weightage (Dinesan et al., 2015; Kumar and Jhariya, 2015; Thapa et al., 2017). Nowadays, GIS-based MCA technique is given prime importance because of its capability to integrate a huge amount of data (Chen et al., 2010; Feizizadeh and Blaschke, 2013; Kumar and Jhariya, 2015). MCA technique provides an ideal output in which the uncertainties incorporated with assessing criteria are rated on the overall behavior of different input parameters with reference to multiple purposes (Aher et al., 2013). In MCA, weightage is given to each factor and ratings assigned to sub classes signify its importance. The combined approach of GIS and MCAallocates effective geographical study (Yu etal., 2009).

Water scarcity and drought prone nature of the study area demands groundwater availability assessment in the watershed.
Keeping in mind the above fact, the present study proposed a methodology utilizing RS, GIS and MCA technique for delineating the groundwater potential zones in the watershed and developing GWPZ map of the study area.

\section{Materials and Methods}

Study area: Kadiri watershed is located in the south-eastern part of Ananthapur distict, Andhra Pradesh, India. This area comprises of four mandals namely, Kadiri, Gandlapenta, Nalla Cheruvu and Obuladevara Cheruvu. The watershed is associated with Madduleru and Somavati Rivers and reserved forest areas namely, Godduvelagala, Kadiri, Tummala North and Kokkanti. The normal annual rainfall is about $553 \mathrm{~mm}$ and average temperature varies from $21.2^{\circ} \mathrm{C}$ to $33.2^{\circ} \mathrm{C}$ in the study area. Most of the area is covered with mixed gravelly soil and its colour varies from brownish yellow to dark brown. Agricultural land use occupies the major portion of watershed which includes agriculture double crop, kharif crop, rabi crop and agriculture fallow land, followed by the second land use extent is the forest area containing dense forest, open forest, forest scrubland and forest plantations. The other land use patterns include wastelands, water bodies and built up areas.

Identification and selection of groundwater potential parameters: The first stage was identification and selection of groundwater potential parameters on the basis of literature review. Recharge of aquifers play an important role in defining the groundwater potentiality of any area. Hence, it is necessary to identify the parameters which control the infiltration process, flow, movement and storage of water in an area. Land use, land cover, slope, geology, geomorphology, soil texture, soil depth, rainfall, drainage density, lineament density are some of the most widely used parameters in assessment of groundwater potential zones of a watershed/catchment. These nine parameters were also used in the present study for delineation of groundwater prospect zones in the watershed.

Development of thematic layers: The second stage was preparation of thematic layers in GIS environment. In the present study, land use land cover map was prepared using IRS P6 LISS IV satellite data of year 2012. Slope map was prepared from Digital Elevation Model (DEM) with $30 \mathrm{~m}$ resolution, downloaded from website of NRSC (Bhuvan). Several collateral data like geology, geomorphology, soil texture, soil depth, rainfall, drainage were also obtained from Geological Survey of India (GSI), National Bureau of Soil Survey Land Use Planning (NBSSLUP) for generating the respective thematic layers. Drainage density map was generated using 'line density' spatial analyst tool in Arc GIS 10.3 software. Lineament density map was prepared using Enhanced Thematic Mapper (ETM) plus technique for the study area.

Assigning weights and ratings to the thematic layers and sub classes: The next stage was to assign the weights to each parameter (layer) and ratings to the subclasses of respective 
layers (parameters). The statistical computation process of relative weights of each parameter (layer) was analyzed using MCA technique, i.e., using multi influencing factor/parameter which may contribute to identify groundwater potential zones. These multi influencing parameters are interdependent and according to the interrelationship between any two parameters, an appropriate weight was assigned to each parameter, respectively. The effect of each major and minor parameter was assigned a weightage of 1.0 and 0.5 , respectively. Similarly, a weightage of 0.0 was assigned to the parameter which signifies no effect with other parameters. Computations of relative ratings were performed considering the cumulative weightage of both major and minor effects. These ratings were further used to calculate the score of each influencing parameter. The proposed score/weight for each influencing parameter is calculated using the procedure suggested by Thapa et al., 2017.

$$
\text { Proposed score }=\left[\frac{(P+Q)}{\Sigma(P+Q)}\right] \times 100
$$

Where $P$ indicates the major effect of parameters and $Q$ indicates the minor effect of parameters. The proposed score obtained for the layers were 20,11, 17, 3, 6, 11, 9, 14 and 9, respectively. All thematic layers were transformed to raster format in GIS for integration. After assigning proposed score/weight as well as rates to the respective subclasses, raster layers were overlaid through Weighted Overlay Technique (WOT) in GIS environment to develop GWPZ map which was further reclassified into five categories, i.e., very poor, poor, moderate, good and very good groundwater potential zones, respectively.

\section{Results and Discussion}

Geological setting of an area plays an important role in the movement and occurrence of groundwater (Manjare, 2014) and groundwater recharge (Yeh et al., 2016). Table 1 shows summary of thematic layers created in GIS environment with their sub classes, weights, ratings and total areal extent with percentage of areal extent. Geology for the study area has been assigned a weight of 20 and divided into five classes such as Grey granite/Pink granite, i.e., $18.40 \%$ of total area (Table 1) with a rating of 6 , Hornblende- biotite gneiss $(71.47 \%$ of total area) with a rating of 20 (Table 1), Meladicite and Melandesite (1.20\% and $6.84 \%$ of total area, respectively) and both rating of 3 (Table 1), Rhyolite/Quartz (2.09\% of total area) with a rating of 12 (Table 1). Different ratings were assigned to different lithological unit depending upon the potentiality of groundwater storage, i.e., infiltration capacity and groundwater recharge potential. High score was assigned to Hornblende-biotite gneiss followed by Rhyolite/Quartz and low to Meladicite and Melandesite. Hornblende-biotite gneiss is relatively porous formation and can be considered as favorable for groundwater storage (Venkateswaren et al., 2014) and given highest priority (Siva et al., 2017). Similarly grey granite/pink granite being relatively less porous, hard (igneous) rock assigned low score for showing very less water availability (Ramu et al., 2014) and low groundwater prospect (Nasir et al., 2018) whereas Rhyolite/Quartz, a fine grained igneous rock in comparison is more porous. Geomorphologic analysis helps in delineation and mapping of various landforms which directly governs the occurrence of subsurface water. It is considered as one of the most important factors in assessing the groundwater potentiality of an area. Geomorphologic units and associated features were used for assessing the groundwater prospect zones by integrating hydrogeological physiographical, structural, geological and drainage condition. The watershed was mainly classified into four basic geomorphologic units namely, Denundation hills, GraniteGneiss (Inselbergs), Pediment-Pediplain and Dyke ridge and thematic weightage assigned of 11 (Table 1).

Pediment-Pediplain were considered as very good groundwater potential zone and assigned a rating of $11(61.17 \%$ of total area) whereas Denundation hills were assigned a rating of $3(8.53 \%)$ (Table 1) were considered unsuitable from groundwater prospect point of view. Arulbalaji and Gurugnanam (2016) reported in their study that pediment-pediplain has very good groundwater prospects and assigned higher ratings whereas low ratings has been assigned to denundation hills due to poor groundwater prospect. Less resistant and fractured parts of the basalt give way to weathering, resulting in the formation of pediments (Saraf and Choudhury, 1998) and when pediments coalesce in a large area, they form a pediplain (Dury and Langford-Smith, 1965) whereas erosion and weathering process creates denudational hill (Ramaiah et al., 2012). Moreover, Pediment and Pediplain have gentle to moderate slope with good infiltration capacity and good groundwater potential where as denundation hills have moderate to steep slope (Rajaveni et al., 2017) with poor infiltration capacity (Ramaiah et al., 2012). Granite-Gneisses (Inselbergs) were assigned a rating of 3 $(29.47 \%)$ (Table 1). Inselbergs are the erosional remnants and fall under very poor to poor groundwater prospective zone (Ganapuram et al., 2009). Similarly, dyke ridge also possess insignificant infiltration capacity, i.e., grouped under poor zones (Ganapuram et al., 2009) and hence assigned a rating of 3 which extends over an area of 4.30 sq.km (Table 1). Henceforth, low groundwater prospect zones were assigned low ratings.

The different properties of soil are necessary to be interpreted because soil properties influence deep infiltration, surface run-off and also with their respective erosive nature which can be defined from soil texture characteristics (Ancona et al., 2010). The soil textures of an area represent the rate of infiltration (Jasrotia et al., 2009) and are also an important parameter for delineating the groundwater potential zones (Thapa et al., 2017). According to the NBSSLUP department, three categories of soil textures were found in the entire study area. The soil textures observed in the study area were rock lands, fine loamy and loamy skeletal covering about $45.64 \%, 38.13 \%, 16.23 \%$ area (Table 1), respectively. The weightage of 17 with ratings 3,7 and 17 (Table 1) has been assigned to the thematic layer. Ratings were assigned on the basis of their rate of infiltration, i.e., higher the infiltration rate, higher the rating and vice versa. Hence, highest 
Table 1: Summary of the thematic layers created in GIS environment with their subclasses, weights, ratings and total areal extent with percentage of areal extent

\begin{tabular}{|c|c|c|c|c|c|}
\hline Layers/Parameters & Sub classes & Weight & Rating & Area (sq.km) & Percentage area $(\%)$ \\
\hline \multirow[t]{5}{*}{ Geology } & Grey granite/Pink granite & 20 & 6 & 95.18 & 18.40 \\
\hline & Hornblende-biotite gneiss & & 20 & 369.70 & 71.47 \\
\hline & Meladacite & & 3 & 6.24 & 1.20 \\
\hline & Melandacite & & 3 & 35.37 & 6.84 \\
\hline & Rhyolite/Quartz & & 12 & 10.79 & 2.09 \\
\hline \multirow[t]{4}{*}{ Geomorphology } & Denundation hills & 11 & 3 & 44.11 & 8.53 \\
\hline & Granite - Gneiss & & 3 & 152.44 & 29.47 \\
\hline & Pediment-Pediplain & & 11 & 316.43 & 61.17 \\
\hline & Dyke ridge & & 3 & 4.30 & 0.83 \\
\hline \multirow[t]{3}{*}{ Soil texture } & Rock lands & 17 & 3 & 236.09 & 45.64 \\
\hline & Fine loamy & & 7 & 197.26 & 38.13 \\
\hline & Loamy skeletal & & 17 & 83.93 & 16.23 \\
\hline \multirow[t]{3}{*}{ Soil depth (cm) } & Rock outcrop (0-25) & 3 & 1 & 148.23 & 28.65 \\
\hline & Shallow depth (25-50) & & 2 & 104.57 & 20.22 \\
\hline & Moderately deep (50-100) & & 3 & 264.48 & 51.13 \\
\hline Drainage Density & $0-0.87$ & 6 & 6 & 91.61 & 17.71 \\
\hline \multirow{4}{*}{$\left(\mathrm{km} \mathrm{sq} \mathrm{km}^{-1}\right)$} & $0.87-1.74$ & & 5 & 172.85 & 33.42 \\
\hline & $1.74-2.61$ & & 4 & 158.88 & 30.71 \\
\hline & $2.61-3.48$ & & 3 & 84.26 & 16.29 \\
\hline & $3.48-4.35$ & & 1 & 9.68 & 1.87 \\
\hline \multirow[t]{4}{*}{ Slope (Degree) } & $<7$ & 11 & 11 & 402.72 & 77.85 \\
\hline & $7-14$ & & 9 & 62.49 & 12.08 \\
\hline & $14-22$ & & 7 & 32.39 & 6.26 \\
\hline & $>22$ & & 4 & 19.68 & 3.81 \\
\hline \multirow[t]{4}{*}{ Rainfall (mm) } & $500-513$ & 9 & 3 & 119.39 & 23.08 \\
\hline & $513-526$ & & 5 & 248.91 & 48.12 \\
\hline & $526-539$ & & 7 & 92.26 & 17.84 \\
\hline & $539-554$ & & 9 & 56.72 & 10.96 \\
\hline Lineament density & $0-0.49$ & 14 & 3 & 287.55 & 55.59 \\
\hline \multirow[t]{4}{*}{$\left(\mathrm{km} \mathrm{sq} \mathrm{km}^{-1}\right)$} & $0.49-0.98$ & & 6 & 142.67 & 27.58 \\
\hline & $0.98-1.47$ & & 8 & 59.02 & 11.41 \\
\hline & $1.47-1.96$ & & 11 & 22.53 & 4.36 \\
\hline & $1.96-2.47$ & & 14 & 5.51 & 1.06 \\
\hline \multirow[t]{7}{*}{ Land use land cover } & Agricultural land & 9 & 9 & 371.17 & 71.25 \\
\hline & Barren Rocky land & & 1 & 15.28 & 2.95 \\
\hline & Built up area & & 3 & 6.85 & 1.32 \\
\hline & Fallow land & & 3 & 9.86 & 1.92 \\
\hline & Forest area & & 6 & 94.32 & 18.23 \\
\hline & Scrub land & & 3 & 18.55 & 3.59 \\
\hline & Water body & & 8 & 1.25 & 0.24 \\
\hline
\end{tabular}

priority was given to loamy skeletal followed by fine loamy and then rock lands (Rashid et al., 2012) in the study area. Soil depth is represented by the thickness of topsoil and its underlying subsoil. As topsoil erodes, the underlying subsoil which has low rainfall infiltration capacity gets exposed to ground surface, resulting in less water availability (Jhariya et al., 2016). Availability of water and effect of run-off is greatly influenced by depth of soil (Kumar and Jhariya, 2015). The soil depth has been grouped into three classes such as rock outcrop, shallow and moderately deep according to the NBSS classification. Rock outcrop ( 0 to $25 \mathrm{~cm}$ ) was assigned a rating of 1 , occupies an area of about $28.65 \%$ (Table 1) is not suitable for groundwater infiltration which signifies very poor groundwater prospect, similarly shallow depth $(25 \mathrm{~cm}$ to $50 \mathrm{~cm})$ assigned a rating of $2(20.22 \%)$ (Table 1 ) also represents low groundwater prospect. Moderately deep $(50 \mathrm{~cm}$ to $100 \mathrm{~cm}$ ) soil depth assigned a rating of $3(51.13 \%)$ (Table 1 ) represents moderate groundwater prospect. Ibrahim-Bathis and Ahmed (2016) has also assigned ratings in the similar trend in their study area, i.e., deeper the soil, higher the rating assigned and vice versa.

Drainage pattern of any study area represents the features of its surface as well as subsurface media. The study area is traversed by two major rivers namely, Madduleru and 
Somavati Rivers. Drainage density (DD) is defined as the proximity of spacing of stream channels. It is a measure of the total length of the stream segment of all orders per unit area. The drainage density and permeability are inversely correlated to each other. If the drainage density of an area is high it indicates less permeable rock structure and increases the runoff within that area (Rashid et al., 2012). Hence, higher drainage density indicates low recharge whereas low drainage density reveals higher recharge (Bagyaraj et al., 2013). In the present study, since DD can be related to permeability and surface run off, it reveals the groundwater potentiality of the area. The drainage density value varied from 0 to $4.35 \mathrm{~km} \mathrm{sqkm}^{-1}$ (Table 1). Drainage density ranges were classified into five categories and assigned a rating of $6,5,4,3$ and 1, respectively, i.e., $0-0.87 \mathrm{~km} \mathrm{sqkm}^{-1}(17.71 \%)$, $0.87-1.74 \mathrm{~km} \mathrm{sqkm}^{-1}(33.42 \%), 1.74-2.61 \mathrm{~km} \mathrm{sqkm}^{-1}(30.71 \%)$, $2.61-3.48 \mathrm{~km} \mathrm{sqkm}^{-1}$ (16.29\%), 3.48-4.35 km sqkm${ }^{-1}$ (1.87\%) (Table 1) for the analysis purpose. Rajaveni et al. (2017) also assigned higher rating to lower range of drainage density because of high groundwater potentiality and vice-versa in their study area. The weightage assigned to the thematic layer was 6 (Table 1).

Slope is one of the important parameters considered for delineation of subsurface water potential zones. In this study area, slope varied between $0^{\circ}$ to $63^{\circ}$. In the study area, slope was classified into four classes, i.e., less than $7^{\circ}(77.85 \%), 7^{\circ}-14^{\circ}$ $(12.08 \%), 14^{\circ}-22^{\circ}(6.26 \%)$ and more than $22^{\circ}(3.81 \%)$ (Table 1$)$. Weight assigned to the thematic layer of slope was 11 (Table 1). Flat slope has been assigned a higher rating, i.e., 11 due to significant groundwater potentiality as rainwater can easily percolate through this zone (Lone et al., 2013). Due to flat surface, runoff will be very less in this area and sufficient time will be available for infiltration of water (Preeja et al., 2011). The major portion of the study area represents flat slope indicating excellent groundwater prospect. Slope ranges between $7^{\circ}$ to $14^{\circ}$ and $14^{\circ}$ to $22^{\circ}$ were assigned with rating 9 and 7 (Table 1). Similarly, slope greater than $22^{\circ}$ (very steep slope) was assigned a rating of 4 indicating insignificant groundwater prospect (Table 1) due to rapid runoff with increased erosion rate and poor groundwater recharge (Basavarajappa et al., 2013). Availability of groundwater in an area depends on rainfall distribution along with the topography which directly influences the infiltration rate of surface runoff. According to the mean annual rainfall, the watershed was classified into four classes as $500-513 \mathrm{~mm}, 513-526 \mathrm{~mm}, 526-$ $539 \mathrm{~mm}$ and $539-554 \mathrm{~mm}$, respectively, with assigned weightage of 9 (Table 1). Higher ratings were assigned to higher rainfall class because of its possibilities to increase groundwater recharge of aquifers in a region. According to the classification, from lower to higher range of rainfall, ratings assigned were $3,5,7$ and 9 to the thematic layer with areal extents, i.e., $119.39 \mathrm{sq.km}$ (23.08\%), 248.91 sq.km (48.12\%), 92.26 sq.km (17.84\%) and 56.72 sq.km (10.96\%) (Table 1). The chance of availability of groundwater is high for areas with higher rainfall thereby indicating higher groundwater potentiality and vice versa (Patra et al., 2018).

Discontinuities in earth's subsurface strata are caused due to geomorphic or geological processes that reflect the presence of lineaments in the area. Lineaments represent a belt of faults and fractures in the rock beds resulting in increased secondary porosity and permeability. High fracture/lineament density represents high groundwater potentiality (Magesh et al., 2012). Hence, lineaments have a significant role in identification of geological features like folds and faults, exploration of minerals and groundwater potential zone identification. It was categorized into five classes as 0-0.49 km $\mathrm{sqkm}^{-1}(55.59 \%), 0.49-0.98 \mathrm{~km} \mathrm{sqkm}^{-1}(27.58 \%), 0.98-1.47 \mathrm{~km}$ $\mathrm{sqkm}^{-1}(11.41 \%), 1.47-1.96 \mathrm{~km} \mathrm{sqkm}^{-1}(4.36 \%), 1.96-2.47 \mathrm{~km}$ $\mathrm{sqkm}^{-1}(1.06 \%)$ (Table 1). Ratings assigned to the classes were, $3,6,8,11$ and 14 , respectively with weightage of 14 (Table 1). Higher the class of lineament density assigned higher rating as representing very good prospective zone.

Distribution of various land use land cover pattern portrays a major role in development of groundwater resources in any region. Gülersoy and Çelik (2017) highlighted in their study that soils should be used according to the land capability classes in order to prevent degradation, erosion and pollution. GIS analysis of remotely sensed data of land use and land cover near water bodies shows important role of groundwater on landscape components (Bogdanets and Anatoliy, 2015). Surface runoff, infiltration and evapotranspiration are controlled by the land use land cover patterns (Chaudhary and Kumar, 2018). Thus, in any watershed area land use land cover have a significant role for

Table 2 : Statistical analysis data of Groundwater Potential Zones parameters ratings such as Minimum, Maximum, Mean, Standard Deviation and Coefficient of Variation

\begin{tabular}{llllll}
\hline Parameters & Minimum & Maximum & Mean & $\begin{array}{l}\text { Standard } \\
\text { deviation (SD) }\end{array}$ & $\begin{array}{l}\text { Coefficient of } \\
\text { variation (CV \%) }\end{array}$ \\
\hline Geology & 3 & 20 & 15.89 & 6.61 & 41.60 \\
Geomorphology & 3 & 11 & 7.89 & 3.90 & 49.43 \\
Soil texture & 3 & 17 & 6.80 & 4.85 & 71.32 \\
Soil depth & 1 & 3 & 2.22 & 0.86 & 38.74 \\
Drainage density & 1 & 5 & 4.01 & 0.96 & 23.94 \\
Slope & 4 & 11 & 10.24 & 1.67 & 16.31 \\
Rainfall & 3 & 9 & 5.33 & 1.81 & 33.95 \\
Lineament density & 3 & 14 & 4.86 & 2.44 & 50.21 \\
Land use land cover & 1 & 9 & 7.81 & 2.13 & 27.27 \\
\hline
\end{tabular}




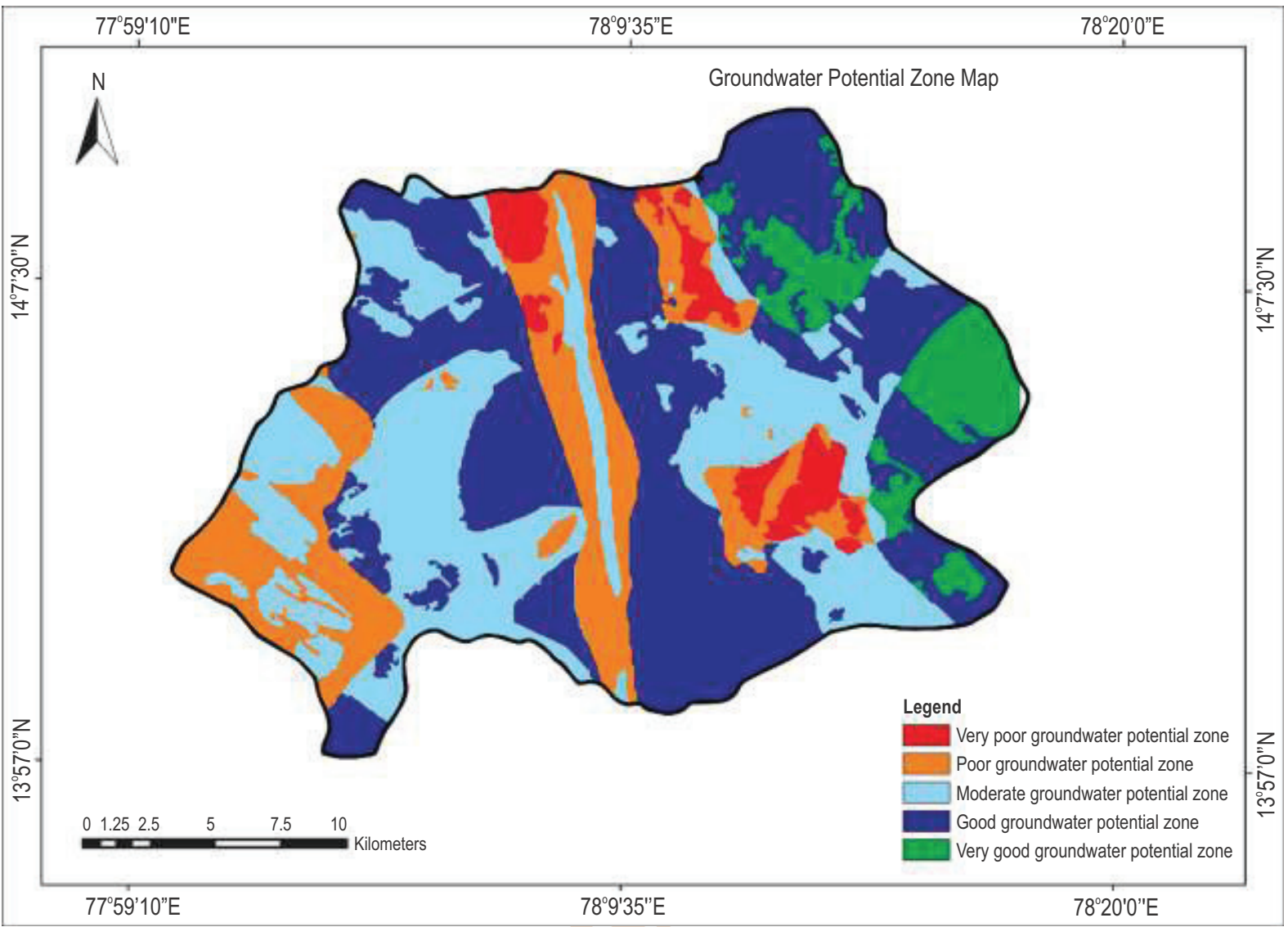

Fig. 1: Spatial distribution map of groundwater potential zone (GWPZ) of Kadiri watershed.

identifying groundwater prospect zones. The classification was done on the basis of their capacity to retain water on ground and to infiltrate water into the ground. Keeping in mind the fact, the study area was categorized into 7 subclasses and assigned weightage of 9 (Table 1) to the thematic layer. Agricultural land extends to an area of about 371.17 sq.km, i.e., $71.25 \%$ (rating-9), barren rocky land cover 15.28 sq.km, i.e., $2.95 \%$ (rating-1), built up area extends to an area of about $6.85 \mathrm{sq} . \mathrm{km}$, i.e., $1.32 \%$ (rating-3), fallow land covers 9.86 sq.km, i.e., $1.92 \%$ (rating-3), forest area occupies 94.32 sq.km, i.e.,18.23\% (rating-6), scrub land occupies $18.55 \mathrm{sq} . \mathrm{km}$, i.e., $3.59 \%$ (rating-3) and water body occupies 1.25 sq. km, i.e., $0.24 \%$ (rating-8) (Table 1 ).

Agricultural area demostrates higher infiltration of water and covers a major part of study area whereas water bodies are the excellent source of recharge of groundwater, both exhibiting excellent groundwater potentiality and thus assigned highest ratings (Jhariya et al., 2016). Chowdary et al. (2008) reported groundwater infiltration is good in forest area and poor in built up area and hence forest area were assigned higher ratings in comparison to built up area. Due to very low infiltration and high runoff, availability of groundwater is very poor in barren rocky land (Ramu et al., 2014) and has been assigned lowest rating. The highest groundwater prospects could be inferred from the high mean rating (Table 2) of the geology parameter (mean rating of 15.89). The presence of the topographic slope, geomorphology, land use land cover and soil texture exhibit intermediate/moderate groundwater prospects, while rainfall, drainage density, lineament density and soil depth implies low groundwater prospects. The soil texture data, with a high coefficient of variation (CV\% $=71.32)$, are highly variable within the study area. The slope and drainage density exhibit the least variability $(\mathrm{CV} \%=16.31$ and 23.94, respectively).

The higher variability of the input parameters implies a greater contribution toward the variation of the groundwater potential zone index and vice versa. Few locations were having very good groundwater potentiality (36.95 sq.km, i.e., 7.14\%) in the study area. Locations having good groundwater prospect covered 206.31 sq. km (39.88\%) area, while moderate and poor zone covered an area of $159.35 \mathrm{sq} . \mathrm{km}$ $(30.81 \%)$ and 91.90 sq.km (17.77\%), respectively. Total area 
of 22.77 sq. km (4.40\%) comes under very poor category. The GWPZ map of the study area is shown in Fig. 1. It was categorized into five subclasses such as Very good, Good, Moderate, Poor, and Very poor. Major portions of very good and good groundwater potentiality occur in the eastern region of the study area. From GIS overlay analysis, it is inferred that groundwater potentiality is predominantly good, except in few central, eastern and Southwestern portion, of the watershed (Fig. 1).

The very good groundwater potential zone (36.95 sq. km) identified was mainly in pediment-pediplain with flat slope $\left(<14^{\circ}\right)$ and due to agricultural practices on loamy skeletal soil. It may be concluded that the presence of relatively higher lineament density $\left(>1.47 \mathrm{~km} \mathrm{sqkm}^{-1}\right)$, flat slope $\left(<14^{\circ}\right)$, and low to moderate drainage density ( 0 to $2.61 \mathrm{~km} \mathrm{sqkm}^{-1}$ ), high rainfall $(>526 \mathrm{~mm}$ per year), agricultural land and distribution of loamy skeletal with shallow to moderate depth $(25 \mathrm{~cm}-100 \mathrm{~cm})$ may be contributing high groundwater potentiality in the eastern region. Similarly, presence of rocky lands, low lineament density $\left(<0.98 \mathrm{~km} \mathrm{sqkm}^{-1}\right)$ and higher slope $\left(>14^{\circ}\right)$ may be responsible for very poor $(22.77$ sq. $\mathrm{km})$ to poor $(91.90 \mathrm{sq} . \mathrm{km})$ groundwater potentiality in the region. Thus, for the exploration of groundwater resources and identification of suitable recharge structure locations, the groundwater potential zone map can be readily utilized by the administrators for the sustainable development of the study area.

\section{Acknowledgments}

Authors would like to acknowledge grants received from Science and Engineering Research Board (SERB), DST, Government of India vide research project no: (SR/FTP/ETA$486 / 2012$ dated 16.12.2016) for carrying out this research project work. The authors are also thankful to organizations like National Remote Sensing Center, Hyderabad, National Bureau of Soil Survey and Land use Planning, Bangalore, Geological Survey of India, Survey of India, Andhra Pradesh State Groundwater Board, Anantapuram Division, District Water Management Agency (DWMA), Anantapuram for providing the necessary data and information utilised in the present work. Authors would like to thank anonymous reviewers for their suggestions for improving the quality of the research paper.

\section{References}

Agarwal, R. and P. K. Garg: Remote sensing and GIS based groundwater potential \& recharge zones mapping using multi-criteria decision making technique. Water Resour. Manag., 30, 243-260 (2016).

Aher, P.D., J. Adinarayana and S.D. Gorantiwar: Prioritization of watersheds using multi-criteria evaluation through fuzzy analytical hierarchy process. Agric. Eng. Int. CIGR J., 11-18 (2013).

Ancona, V., D.E. Bruno, N. Lopez, G. Pappagallo and A.V. Uricchio: Modified soil quality index to assess the influence of soil degradation processes on desertification risk. CNR-National Research Council-IRSA. Ital. J. Agronomy., 3, 45-55 (2010).

Arulbalaji, P. and B. Gurugnanam: An integrated study to assess the groundwater potential zone using geospatial tool in Salem district, South India. J. Hydrogeol. Hydrol. Eng., 5, 1-7 (2016).
Bagyaraj, M., T. Ramkumar, S. Venkatramanan and B. Gurugnanam: Application of remote sensing and GIS analysis for identifying groundwater potential zone in parts of Kodaikanal Taluk, South India. Front. Earth Sci., 7, 65-75 (2013).

Basavarajappa, H.T., S. Dinakar, M.V. Sathish, D. Nagesh, A. Balasubramanian and M.C. Manjunatha: Delineation of groundwater potential zones in hard rock terrain of Kollegal Shear Zone (Ksz), South India using remote sensing and GIS Int. J. Earth Sci. Eng., 6, 1185-1194 (2013).

Bogdanets, V. and V. Anatoliy: Analysis of land use changes near large water bodies in Ukraine using GIS, J. Environ. Biol., 36 Special issue, 37-41 (2015).

Chaudhary, B. S. and S. Kumar: Identification of groundwater potential zones using remote sensing and GIS of K-J Watershed, India. J. Geol. Soc. India., 91, 717-721 (2018).

Chen, Y., S. Khan and Z. Paydar: To retire or expand. A fuzzy GIS-based spatial multi-criteria evaluation framework for irrigated agriculture. Irrig. Drain., 59,174-188. DOI: 10.1002/ird.470 (2010).

Chowdary V. M., R. V. Chandran, N. Neeti, R. V. Bothale, Y. K. Srivastava, P. Ingle, D. Ramakrishnan, D. Dutta, A. Jeyaram, J. R. Sharma and R. Singh: Assessment of surface and sub-surface waterlogged areas in irrigation command areas of Bihar state using remote sensing and GIS. Agr. Water Manag., 95, 754-766 (2008)

Dinesan, V.P., G. Gopinath and M.K. Ashitha: Application of geoinformatics for the delineation of groundwater prospects zones-a case study for Melattur Grama Panchayat in Kerala, India, International Conference on Water Resources, Coastal and Ocean Engineering (ICWRCOE 2015). Aqua. Procedia., 4, 13891396 (2015).

Dury, G. H. and T. Langford-Smith: Pediment- pediplain. Aust. Geogr., 9, 386-387(1965).

Feizizadeh, B. and T. Blaschke: Land suitability analysis for Tabriz County, Iran: A multi-criteria evaluation approach using GIS. J. Environ. Plann. Manag., 56, 1-23 (2013).

Ganapuram, S., G.T. Vijaya Kumar, I.V.M. Krishna, E. Kahya and M. Cüneyd Demirel: Mapping of groundwater potential zones in the Musi basin using remote sensing data and GIS. Adv. Eng. Software, 40, 506-518 (2009).

Gülersoy, A. E. and M. A. Çelik: Temporal change of land use in the protection basin of Tahtali Dam (1990-2015), (Izmir, Turkey). J. Environ. Biol., 38, 1061-1067 (2017).

Gupta, M. and P. K. Srivastava: Integrating GIS and remote sensing for identification of groundwater potential zones in the hilly terrain of Pavagarh, Gujrat, India. Water Int., 35, 233-245 (2010).

Ibrahim-Bathis, K. and S.A. Ahmed: Geospatial technology for delineating groundwater potential zones in Doddahalla watershed of Chitradurga district, India. Egypt. J. Remote Sens. Space Sci., 19, 223-234 (2016).

Jasrotia, A.S., A. Majhi and S. Singh: Water balance approach for rainwater harvesting using remote sensing and GIS techniques, Jammu Himalaya, India, Int. J. Water Res. Manag., 23, 3035-3055 (2009).

Jhariya, D.C., T. Kumar, M. Gobinath, P. Diwan and N. Kishore: Assessment of groundwater potential zone using remote sensing, GIS and multi criteria decision analysis techniques. J. Geol. Soc. India., 88, 481-492 (2016).

Kumar, T. and D.C. Jhariya: Land quality index assessment for agricultural purpose using multi-criteria decision analysis (MCDA), Geocarto Int., 30, 822-841 (2015).

Leblanc, M., C. Leduc, M. Razack, J. Lemoalle, D. Dagorne and L. Mofor: Application of Remote sensing and GIS for groundwater modeling of large semiarid areas: example of the Lake Chad Basin, Africa. 
In: Hydrology of Mediterranean and Semiarid Regions Conference, Montpieller, France. Red Books Series, 278. IAHS, Wallingford, pp. 186-192 (2003).

Lone, M. S., D. Nagaraju, G. Mahadavesamy and S. Siddalingamurthy: Applications of GIS and Remote sensing to delineate artificial recharge zones (DARZ) of groundwater in H. D. Kote taluk, Mysore district, Karnataka, India. Int. J. Remote. Sens. Geosci., 2, 92-97 (2013).

Magesh, N. S., N. Chandrasekar and J. P. Soundranayagam: Delineation of groundwater potential zones in Theni district, Tamil Nadu, using remote sensing, GIS and MIF techniques. Geosci. Front., 3, 189196 (2012).

Mallick, J., C. K. Singh, H. Al-Wadi, M. Ahmed, A. Rahman, S. Shashtri and S. Mukherjee: Geospatial and geostatistical approach for groundwater potential zone delineation. Hydrol. Process., 29, 395$418(2015)$

Manjare, B. S.: Identification of groundwater prospecting zones using remote sensing and GIS techniques in upper Vena river watersheds Nagpur district, Maharashtra, India. $15^{\text {th }}$ Esri India User Conference 2014, pp. 1-14 (2014).

Nasir, M. J., S. Khan, H. Zahid and A. Khan: Delineation of groundwater potential zones using GIS and multi influence factor (MIF) techniques: A study of district Swat, Khyber Pakhtunkhwa, Pakistan. Env. Earth Sci., 77, 367 (2018).

Patra, S., P. Mishra and S. C. Mahapatra: Delineation of groundwater potential zone for sustainable development: A case study from Ganga Alluvial plain covering Hooghly district of India using remote sensing, Geographic Information System and Analytic hierarchy process. J. Clean. Prod., 172, 2485-2502 (2018).

Preeja, K. R., J. Sabu, T. Jobin and H. Vijith: Identification of groundwater potential zones of a tropical river basin (Kerala, India) using remote sensing and GIS techniques. J. Indian. Soc. Remote. Sens., 39, 83-94 (2011).

Rajaveni, S.P., K. Brindha and L. Elango: Geological and geomorphological controls on groundwater occurrence in a $\mathrm{h}$ a r d rock region. Appl. Water Sci., 7, 1377-1389 (2017).

Ramaiah, S.N., G.S. Gopalakrishna, S.S. Vittala and Md. Najeeb: Geomorphological mapping for identification of groundwater potential zones in hard rock areas using geo-spatial information-a case study in Malur Taluk, Kolar district, Karnataka, India. Nat. Environ. Pollut. Technol., 11, 369-376 (2012).
Ramu, B. Mahalingam and M. Vinay: Identification of ground water potential zones using GIS and Remote Sensing Techniques: A case study of Mysore taluk-Karnataka. Int. J. Geomat. Geosci., 5, 393-403 (2014).

Rashid, M., M. A. Lone and S. Ahmed: Integrating geospatial and ground geophysical information as guidelines for groundwater potential zones in hard rock terrains of south India. Environ. Monit. Assess., 184, 4829-4839(2012).

Saraf, A. K. and P.R. Choudhury: Integrated remote sensing and GIS for groundwater exploration and identification of artificial recharge sites. Int. J. Rem. Sens., 19, 1825-1841 (1998).

Singha, S., S. Pasupuleti, S. Singha and V.G.K. Villuri: An integrated approach for evaluation of groundwater quality in Korba district, Chhattisgarh using Geomatic techniques. J. Environ. Biol., 38, 865-872 (2017).

Siva, G., N. Nasir and R. Selvakumar: Delineation of groundwater potential zone in Sengipatti for Thanjavur District using Analytical Hierarchy Process. IOP Conf. Series : Earth and Environmental Science., 80, 1-13(2017).

Thapa, R., S. Gupta, S. Guin and H. Kaur: Assessment of groundwater potential zones using multi-influencing factor (MIF) and GIS: A case study from Birbhum district, West Bengal. Appl. Water Sci., 7, 4117-4131 (2017).

Tweed, S. O., M. Leblanc, J. A. Webb and M. W. Lubczynski: Remote sensing and GIS for mapping groundwater recharge and discharge areas in salinity prone catchments, southeastern Australia. Hydrogeol. J., 15, 75-96 (2007).

Venkateswaran, S., M. Vijay Prabhu and S. Karuppannan: Delineation of groundwater potential zones using geophysical and GIS techniques in the Sarabanga sub basin, Cauvery River, Tamil Nadu, India. Int. J. Curr. Aca. Rev., 2, 58-75 (2014).

Wieland, M. and M. Pittore: A spatio-temporal building exposure database and information life-cycle management solution. ISPRS Int. J. Geo Inf., 6, 1104 (2017).

Yeh, Hsin-Fu., Youg-Sin. Cheng, Hung-I. Lin and Cheng-Haw. Lee: Mapping groundwater recharge potential zone using a GIS approach in Hualian River, Taiwan. Sustain. Environ. Res., 33-43 (2016).

Yu, J., Y. Chean and J. P. Wu: Cellular automata and GIS based land use suitability simulation for irrigated agriculture: $18^{\text {th }}$ world IMACS/ MODSIM Congress July, Cairns, Australia, pp. 13-17 (2009). 